\title{
WHAT LIES BEHIND THE STUDENTS' NEED IN ENGLISH FOR SPECIFIC PURPOSES: A REFLECTION OF NEEDS ANALYSIS
}

\author{
Umi Rachmawati
}

English Lecturer, Faculty of Economics and Business,

Universitas Muhammadiyah Magelang, Indonesia

Corresponding Author Email: rachma15315@gmail.com

\begin{tabular}{|c|c|}
\hline Article Info & Abstract \\
\hline $\begin{array}{l}\text { Article History } \\
\text { Received: March } 2020 \\
\text { Revised: April } 2020 \\
\text { Published: April } 2020\end{array}$ & $\begin{array}{l}\text { This study was a need analysis study as a part of the research and development } \\
\text { of instructional materials for English for Business (EFB) at Universitas } \\
\text { Muhammadiyah Magelang. This study was aimed at finding the students' needs } \\
\text { on their EFB course in terms of their personal characteristics, English }\end{array}$ \\
\hline $\begin{array}{l}\text { Keywords } \\
\text { Writing instructions; } \\
\text { ELT learning; } \\
\text { Communicative learning; }\end{array}$ & $\begin{array}{l}\text { proficiency assumption, learning motivation, and personal interest in their } \\
\text { learning English. This study was conducted in a qualitative study that involved } \\
\text { the nature of the qualitative study in nature. The findings of the study indicated } \\
\text { that (1) the students' were adolescents that were ready and conscious to get the } \\
\text { lesson, (2) the students felt that they did not have good English mastery, (3) the } \\
\text { students' motivation in learning individually was not as high as learning in } \\
\text { groups though they realized that they needed to master the target language, and } \\
\text { (4) the students' preferred to have more topics on Islamic values and functions in } \\
\text { English and teacher's roles are planner, information provider, and resource } \\
\text { developer. }\end{array}$ \\
\hline
\end{tabular}

How to cite: Rachmawati, U. (2020). What lies behind the students' need in English for specific purposes: A reflection of needs analysis. JOLLT Journal of Languages and Language Teaching, 8(2), 213-221. DOI: https://doi.org/ 10.33394/jollt.v\%vi\%i.2537

\section{INTRODUCTION}

The concept of teaching and learning is undergone from several aspects especially from the teachers or lecturers to succeed in the achievement of the goals. These include the needs of teaching and learning. The instructional needs deal with the expected goals of the learning saturated from the fields and the students' needs in learning. The expected learning goals influence the main learning materials and activities. The students' needs and wants in learning can modify the way of the teaching to have more engaging and motivating learning.

To meet the goals of the instruction in English for Specific Purposes (ESP), the major requirement of the teaching and learning preparation is conducting a needs analysis. All justified content and method in the teaching of ESP are derived from the learners (Hutchinson \& Waters, 1987). The approach implemented in teaching and learning is influenced by students' learning needs, wants, and lacks. The learning materials, activities, and tasks are developed from the data gathered in the needs analysis to make the teaching and learning in line with the teacher's and the students' expectations.

Experts have justified that the process of teaching should be initialed with a need analysis. Conducting needs analysis will give a direct view of the teachers or lecturers before they start their teaching. Through needs analysis, it is possible for teachers to get the required and expected learning needs and wants (Haerazi \& Irawan, 2020). The needs analysis will also keep the teachers to achieve the main goals of their learning and it will make the learning well guided. As mentioned earlier, the needs analysis is done to know the learners' characteristics that should be done at the beginning of the teaching and learning process of 
each learning cycle. Mostly, the needs analysis will be done before the syllabus is created in a certain course. The teacher and the curriculum developer start the needs analysis by gathering data about the target learners. This can be done through interview or/and questionnaire to the target learners. a number of stages of needs analysis include determining goals, determining boundaries of the use, limits of the test, choosing the data collection tool, collecting evidence, evaluating the data, and criticizing the effectiveness of the study (Sönmez, 2019). The data gathered will be the basis of the development of the instruction implemented in the ESP including curriculum, syllabus, lesson plans, learning materials, and learning activities.

The implementation of the needs analysis has been done and discussed in a number of ways. Sönmez found that researches on needs analysis were done to identify and analyze the language education needs regarding the teacher and student factors. Further, the instructors are expected to gather information from professionals and graduates to be able to address the target situation (Chovancova, 2014). Focusing the needs analysis on the students' learning lacks is also influenced research done by Alsamadani (Alsamadani, 2017). The study presents that students need more learning in writing and reading than other skills. The EFL teachers' beliefs and views toward the implementation of a needs analysis are to be a significant factor to succeed the development of ESP materials (Ibrahim, Ali, Rahman, \& Salih, 2013). Those findings show that all members of the instruction share positive beliefs and views on the implementation of the needs analysis. The focus of their studies was on the method of conducting needs analysis and the teachers' perspectives on conducting the needs analysis. There should be more research on the students' perspectives on a needs analysis for their own learning goals.

The current study was aimed at gathering more information on the needs analysis that focuses on both the students' perspectives on conducting needs analysis for the class of English for Specific Purposes. The discussion of the study involved students' personal characteristics, students' personal English proficiency assumption, students' learning motivation, and students' personal interest to learn English. The specific target was the initial preparation in applying a classroom action research to the development of a handbook of English for Business. The compilation of the students learning needs wants, and lacks would become the major source of the development.

\section{Review of literature Needs Analysis}

Needs analysis can be simply conducted to share what and how a course is developed (Lynne Flowerdew, 2013). It is understood as a process of gathering information from the members of the instruction to deal with the preparation of the instructional process. Need analysis is done to present what and how a certain course that includes course development, curriculum design, materials selection, teaching methodology, and evaluation (Lynne Flowerdew, 2013). This is very crucial in the development of English for Specific Purposes (Saragih, 2014). The needs analysis done in ESP is to address the language requirement in the contexts of the learners (Dudley-Evans \& St John, 1998). It is clear that the initial process of conducting English for specific purposes should need analysis.

Actually, needs analysis is aimed at several reasons as proposed by (Sönmez, 2019). First, the needs analysis is done to seek information on the students' purposes of enrolling in the program. It deals with the sources and current situation to present information on the effectiveness of the ESP program. Second, needs analysis presents information on preferred learning, language skills, and the teachers' and students' roles. Third, needs analysis provides information dealing with the preferences in teaching and learning activities.

Furthermore, there are a number of aspects that deal with the needs analysis as used by Saragih (2014). They are target situation analysis, wants, means, and subjective needs 
analysis, present situation analysis, lack analysis, learning needs analysis, linguistic analysis, and means analysis. The target situation analysis deals with the tasks and activities in the ESP. The wants, means, and subjective need analysis are the personal information affecting the way the students learn. Then, the present situation analysis is the present students' language skills. The lack is actually distinct from the target situation and the present situation analysis. The learning needs and linguistics analysis are effective ways of learning the communication information about the target language. Lastly, the means analysis is the environment in which the instruction will be run.

The process of need analysis consists of several aspects that might be linear and cyclical (Dudley-Evans \& St John, 1998). It can be seen in Figure 1 as follows.

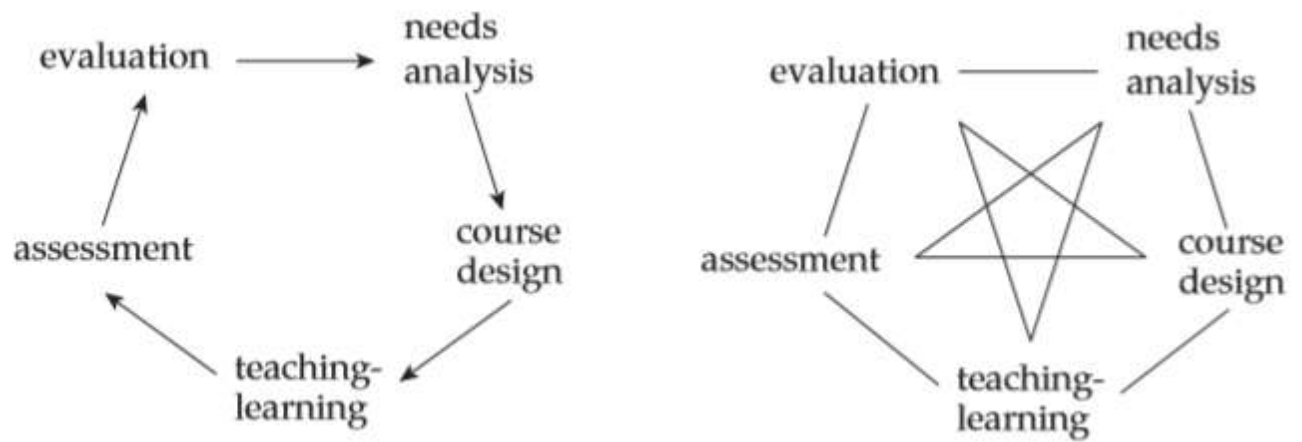

Figure 1. Linear and Cyclical Process of Needs Analysis (Dudley-Evans \& St John, 1998)

\section{English for Specific Purposes (ESP)}

English for specific purposes is understood as the process of teaching and learning English as a foreign language used in a particular domain or area (Paltridge \& Starfield, 2013). The justification of the particular domain lies in the content and aims of the course. The focus of the course is on the language, skills, and the genres merge to the activities that the learners need.

One research that commonly done by the ESP developer is classroom-based research. It focuses on the specific needs and expectations of the ESP students in a different context that is revealed in the course objectives (Cheng, 2011). The results of the classroom research provide more authentic and close to the particular target learners. Particularly on the students' characteristics that can be different from others. By providing a more subject-oriented course in ESP, the teacher can help the students to achieve the objectives of their learning.

As mentioned earlier, this study sought the needs analysis of the use of English for Specific Purposes in the business context. Business English places language teaching and its processes on the diversity of business activities and context (Bargiela-Chiappini \& Zhang, 2013). The theories and methods of international business and cultural management are considered as basic components of international business communication programs. The teaching of English for business is materials-driven and teaching-lead movement. The teaching materials include business negotiations, business meetings, business discourse, business management, business promotion, and other topics related to business management and accounting.

In addition, the teaching of English for Specific Purposes considers the genre, discourse, language, and multimodality. Genre refers to the communicative events in a certain domain. Discourse means communication in speech or writing. Language deals with the linguistics and semantics aspects of the domain used in specific settings and genres. Finally, multimodality is the presentation of the language used. This can be literacy, document design, and visualization. There are four kinds of visuals used in presentations namely; scriptural, 
numerical, figurative, and graphical visuals. Those types of visualization enable the readers to have a complete image of the topic discussed by the writer or speaker. The genre, discourse, language, and multimodality directly influence the visualization.

\section{RESEARCH METHOD}

This study is done through a survey in which a survey is done to describe, compare, and evaluate the data of the study (Akker, Bannan, Kelly, Plomp, \& Nieveen, 2013). In this study, the researcher collected data through a questionnaire given to all of the subjects of the study since the survey was done to encompass values (Ker, Chan, Fields, Beck, \& Rosenstiel, 2008). The research was initially done by conducting a literary study to develop the questionnaire, developing the questionnaire from the literary study, collecting the data from the questionnaire, coding the data, and analyzing the data. The first step of the study, conducting literary study was done by collecting any information from both the related reference and other studies on the same topic. Then, the blueprint of the questionnaire was developed based on the data of the literary study. From the blueprint, the questionnaire was developed and validated by the experts. Next, the questionnaire was given to the subject of the study through online survey. Online survey was done only for the visualization of the questionnaire though the subjects filled the questionnaire guided and accompanied by the researcher. After being collected, the data were coded and analyzed. The data analysis was done quantitatively and qualitatively.

\section{Research Design}

This study was a survey study that considered the use of qualitative data. Therefore, this study belonged to qualitative research instead of the mixed method that enrolled in the collection of qualitative and quantitative data to explore positivistic and naturalistic paradigms (Halcomb \& Hickman, 2015). The qualitative study was done to reveal the emic of the findings to get a deeper understanding of the subject of the study. The issue of the study used immediate and local meanings of actions from the researcher's point of view to get a rich description of the study (Erickson, 1985).

\section{Subject of the Study}

The target subjects of the study were the students of the Faculty of Economics and Business at Universitas Muhammadiyah Magelang who took English for Business in the academic year of 2019/2020. The number of the subjects was 235 students consisting of 155 female students and the rest were male. There was no exception for the students due to the limited number of the target subjects.

\section{Instruments}

The survey conducted in this study was done through the use of questionnaire presented in digital or online media. The respondents were asked to fill the questionnaire through Google form. To control the respondents' responses, the researcher accompanied the respondents during their activity in giving feedback on the questionnaire. This was done to give direct guidance whenever the respondents faced difficulties in filling the questionnaire. This was also to control the respondents in giving feedback based on their real experience. Actually, there were a number of questions addressed that had been classified into several aspects; needs, wants, and lacks. However, those aspects were compiled in one questionnaire. This was done to make the respondents easier to give responses to the questions.

\section{Data Analysis}

The data taken from the questionnaire can be classified as qualitative. The data analysis was done through a qualitative approach. The qualitative data were analyzed by coding the data and reveal the emic of the qualitative data through its descriptive qualitative way. The 
analysis of the qualitative data was compared to the existed theories and previous research findings. This was done to strengthen the findings of the study.

\section{RESEARCH FINDINGS AND DISCUSSION Research Findings}

The first aspect is the respondents' background including their study program, previous learning experience, and mother tongue. First, there were two major study programs in the Faculty of Economics and Business in Universitas Muhammadiyah Magelang; management and accounting study programs. The number of students in the Management study program was 173 and the number of students of the accounting study program was 62 .

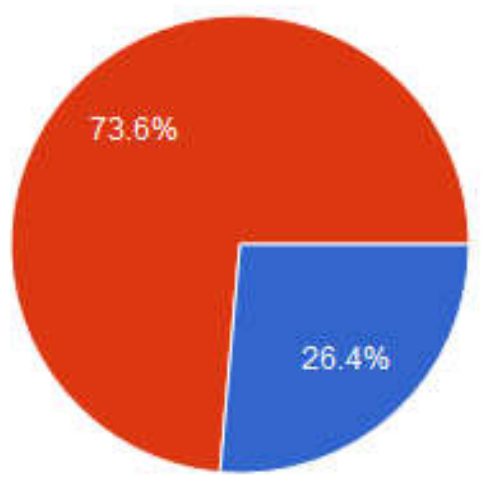

Figure 2. The Student's Study Program Distribution

The number of female students was 155 students and the number of male students was 80 while the age of the students was varied. The number of students in the age of 17-19 was 167, 20-22 was 65 students, and the rest was in the age of 23-25. Most of the students graduated from senior high school (76.6\%) and $23.4 \%$ of the respondents graduated from vocational high school. Related to the students' mother tongues, most of them used Javanese and Bahasa Indonesia as their mother tongues. This was due to the students are commonly from Java where Javanese and Bahasa Indonesia were the most common languages used in this island.

However, in Java especially in Central Java, most of the schools had other foreign languages taught at schools. In spite of Bahasa Indonesia that was mastered by $98.3 \%$ of the respondents, and English was by $21.7 \%$, Korean became the third foreign language mastered $(1.7 \%)$. Mandarin and Japanese were the least foreign languages mastered $(0.2 \%)$. The five languages represented the way the students in learning foreign languages for their own purposes.

The second aspect of the need analysis was the students' lack of mastering the target language. The first question addressed was their language mastery, in which $42.6 \%$ of the respondents declared that their English mastery was poor. Following it, 39.6\% of the respondents had average English mastery. Then, 11.5\% of the respondents had good English mastery. Meanwhile, only $3.4 \%$ of the respondents were very poor at their English mastery and $3 \%$ of them were good at their English proficiency.

There are different percentages of the students' language masteryclassified into the four language mastery; listening, speaking, reading, and writing. For listening, 36.2\% of the respondents had the average listening skill, $31.1 \%$ had poor language mastery, $28.1 \%$ had the fair listening mastery, and the rest of them had good listening mastery. Moreover, the respondents' reading skills were mostly in average rate $(60.4 \%)$ followed by fair mastery $(26 \%)$, good reading mastery $(7.7 \%)$, and poor reading mastery $(6 \%)$. The respondents' writing skill mastery was classified into four levels; good (5.5\%), average (39.1\%), fair 
(30.6\%), and poor $(24.7 \%)$. Finally, the students' speaking skills were also classified into 4 levels of language mastery; good (3\%), average (31.9\%), fair (30.6\%), and poor (34.5\%).

In addition, the details of the language proficiency were supported by the vocabulary, pronunciation, and grammar. Based on the data gathered, the English vocabulary skill was classified into four levels; fair (35.7\%), poor (33.6\%), average $(28.9 \%)$, and good $(1.7 \%)$. The respondents' pronunciation was also classified into four levels; fair $(32.8 \%)$, poor $(31.5 \%)$, average $(33.2 \%$, and good (2.1\%). Finally, the English grammar was responded in four levels; poor $(48.5 \%)$, fair $(30.2 \%)$, average (19.1\%), and good (2.1\%). Those skills are considered to be important in mastering the four language skills; listening, speaking, reading, and writing.

In relation to the students' needs, the respondents agreed that they needed to improve their reading skills (161 respondents). The second skill was the writing skills needed by the respondents (154 respondents). Hence, 135 respondents agreed that pronunciation should also be mastered. Vocabulary mastery, grammar, listening, and speaking skills were in order from the most until the least number of the respondents. Based on the data, the respondents agreed on the improvement of the skills rather than the strongly agree, disagree, and strongly disagree.

Based on the data on the activities that the respondents wanted to have during their English for Specific Purposes, working in a small group of 3-5 was the biggest percentage (68.5\%). Working more than five people in a group was preferred by $25.5 \%$ of the respondents. The individual working activity was preferred by $15.7 \%$ of the respondents while working in pairs was preferred by $13.2 \%$ of the respondents. The learning materials that the respondents wanted to have were participating in group discussion, email writing, memo writing, learning business terms, listening for accurate understanding, reading to get the main idea (skimming), face-to-face negotiation, reading critically, making polite conversation with the clients, business report writing, dealing with clients' objections, and giving an oral presentation. Those learning activities and materials are highly preferred by the target learners

To support the students' reading mastery, the topics for the reading activities should be considered. Based on the data gathered, a number of topics are very necessary for the students. They are the relationship between humans and Allah, the relationship between humans and society, akhlakul karimah, and self-development. One topic that is necessary is about nature or society. Those topics are an addition to topics that the students are good at. Love, friendships, and peace are the topics that the students are good at while topics about love, courage, heroism, freedom, ethical code and greed are average for the students.

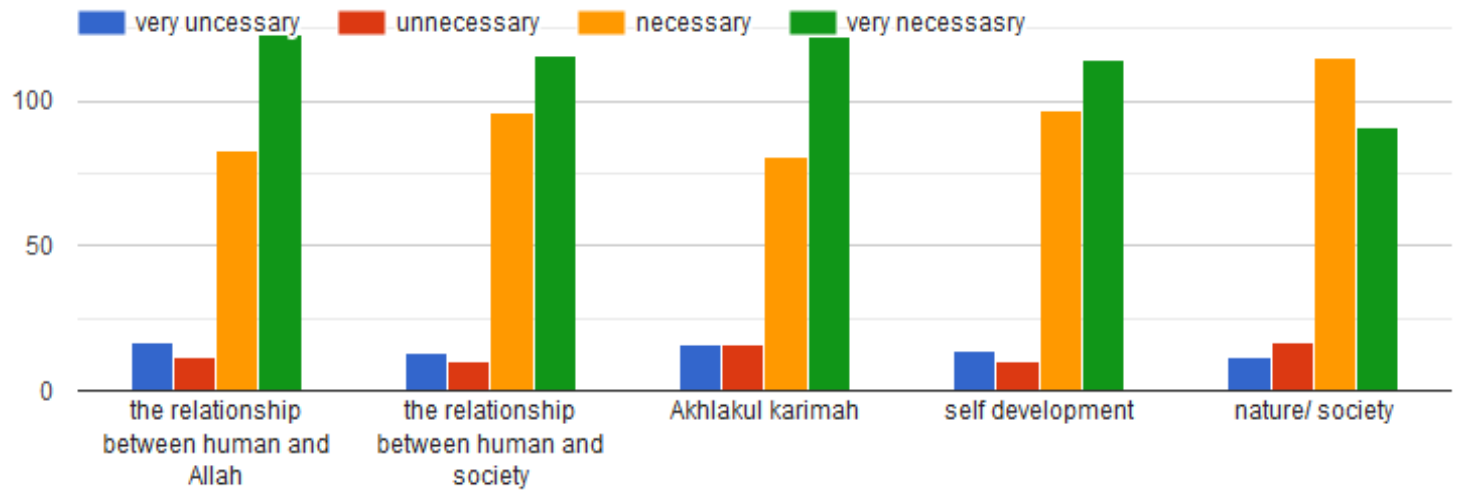

Figure 3. Topics of the Learning Materials Preferred by the Students

The last aspect is the teacher's roles during the class in which they are expected to be a planner, resource developer, information provider, manager, facilitator, participant, role model, and assessor. The planner, information provider, and resource developer are the top 
three roles that preferred by the students. The teacher's roles are crucial to succeed in the teaching and learning goals.

\section{Discussion}

In this section, the writer divides the discussion into a number of classifications based on the findings gathered. The discussion is presented in the following aspects; students' personal characteristics, students' personal English proficiency assumption, students' learning motivation, and students' personal interest to learn English. Each aspect is elaborated briefly in this part.

First, students' personal characteristics are considered to be a crucial element in achieving the success of language teaching. The students' maturity to deal with the language teaching influences the way they respond to the instruction and the activities during the class. Mostly, the students are in the age of 17-19 in which they are ready to enroll in the class. They also realize the process and the purpose of their learning. Students belong to the adolescent that has good cognitive control (Iselin, Decoster, \& Salekin, 2009) to support their learning. It means that the students can be their own controller in learning to achieve their purpose of learning.

Second, the students' personal English proficiency assumption is also considered to see the students' personal point of view about their English proficiency. The highest percentage of students' English proficiency is poor. They justify their English mastery as poor. It means that they do not have high self-esteem in their English proficiency. Underestimating themselves, the students will have difficulties in learning English since they have been confused even before the lesson starts. Therefore, the students will not master the target language if the teacher does not encourage the students before teaching. The teacher needs to develop the students' self-esteem and share a positive view of the learning of the target language. the students' self-esteem directly influences the language learning strategies in terms of effective and strategy use (Asadifard \& Biria, 2013).

Third, the students' English learning motivation is viewed as an indicator to succeed the teaching and learning. This can be seen from the students' responses to the learning activities they expected to have during the learning. The language skills that are needed by the students are the reading skill and followed by writing and pronunciation skills. It means that the students have high motivation to have more activities dealing with the written texts that can be accessed and implemented in their daily communication. It is in line with Haerazi, Prayati, and Vikasari (2019) who state motivation plays an important role to acquire language skills. In addition, students expect to have reading activities motivating themselves which is effected by the techniques in teaching EFL reading (Cahyono \& Widiati, 2006; Hadi, 2020). Having good reading skills, the students can support their writing mastery since writing plays an important role in personal and professional life (Wahyuni, 2017). Then, the mastery of pronunciation is actually to support the students' speaking performance since they have low pronunciation mastery. It can be seen from their response to the speaking class that they have very low pronunciation mastery.

The final aspect is the students' personal interest in learning English for specific purposes. This includes the students' preferences in their learning activities, materials, and teacher's roles. The students prefer to have more learning activities that involve 3-5 students. It means that the students do not have high motivation and self-confidence to work individually. Then, the learning materials deal with the topics and the language functions the students need during their learning of English for specific purposes. The language functions are email writing, memo writing, learning business terms, negotiating, making polite conversation, dealing with clients' objectives, and presenting in English. The topics that the students expect at most are the relationship between human and Allah, human, and society, 
akhlakul kharimah, and self-development. The proper selection of learning topics and language functions may merge well with the students' personal and professional lives.

Finally, the teacher's roles in the lessons are varied as mentioned in the previous part. The most role that the students want to have from their teacher is the teacher as planners. The teacher should be able to make the best plan for the students' learning in line with the students' learning goals. The teacher needs to be a source developer instead of only using the existed learning resources. This is to support the teacher's role as an information provider. Being a manager for the students is also needed to manage and control the students' learning process and achievement. The last two roles for the teacher are becoming role models and assessors. Being a role model in English proficiency and attitude in learning EFL, the assessor helps the students to control their learning achievement. Those teacher's roles directly influence the preparation, process, and evaluation of the teaching.

\section{CONCLUSION}

The main data of the study include several findings. First, the students of English for Business are teenagers who are ready and conscious to enroll in the lesson. Second, there is a clear belief in the students' lack of English mastery. Third, classroom management should facilitate the students to have more group work activities to improve their learning motivation. Fourth, dealing with the use of Islamic values in business English, topics on Islamic values are preferred by the students to deal with the functions in English with the help of the teacher as a planner, information provider, and resource developer.

\section{ACKNOWLEDGMENT}

This study is conducted within the support of the Institute for Research and Community Services of Universitas Muhammadiyah Magelang. The institute is also recommended to provide funding body who give financial support (grant) to the study.

\section{REFERENCES}

Akker, J. van den, Bannan, B., Kelly, A. E., Plomp, T., \& Nieveen, N. (2013). Educational Design Research. (T. Plomp \& N. Nieveen, Eds.). Enschede: Netherlands Institutre for Currculum Development.

Alsamadani, H. A. (2017). Needs Analysis in ESP Context: Saudi Engineering Students as a Case Study. Advances in Language and Literary Studies, 8(6), 58-68.

Asadifard, A., \& Biria, R. (2013). Affect and Strategy Use : The Relationship between EFL Learners "Self -esteem and Language Learning Strategies. Theory and Practice in Language Studiess, 3(9), 1685-1690. https://doi.org/10.4304/tpls.3.9.1685-1690

Bargiela-Chiappini, F., \& Zhang, Z. (2013). Business English. In B. Paltridge \& S. Starfield (Eds.), The Handbook of English for Specific Purposes (pp. 193-211). West Sussex: John Wiley \& Sons, Inc.

Cahyono, B. Y., \& Widiati, U. (2006). The teaching of efl reading in the indonesian context: the state of the art. TEFLIN Journal 17, 17(1), 36-58.

Cheng, A. (2011). ESP Clasroom-Based Research: Basic Considerations and Future Research Questions. In New Directions in English for Specific Purposes Research (pp. 44-72). MI: University of Michigan Press.

Chovancova, B. (2014). Needs analysis and esp course design: Self-perception of language needs among pre-service students. Studies in Logic, Grammar, and Rhetoric, 38(51), 4357. https://doi.org/10.2478/slgr-2014-0031

Dudley-Evans, T., \& St John, M. J. (1998). Developments in English for Specific Purposes- a 
multi-disciplinary approach. Cambridge: Cambridge.

Erickson, F. (1985). Qualitative methods in research on teaching. Institute for Research on Teaching.

Hadi, M. (2020). Exploring the teaching and learning belief of an Indonesian English teacher. JOLLT Journal of Languages and Language Teaching, 8(1), 29-39. doi: https://doi.org/10.33394/jollt.v8i1.2222

Haerazi, H., \& Irawan, L. (2020). Developing Intercultural Language Learning (ILL) model to teach writing skills at Indonesian private universities. EduLite: Journal of English Education, Literature and Culture, 5(1), 43-54. DOI: http://dx.doi.org/10.30659/e.5.1.43-54

Haerazi, H., Prayati, Z., \& Vikasari, R. M. (2019). Practicing contextual teaching and learning (CTL) approach to improve students' reading comprehension in relation to motivation. English Review: Journal of English Education, 8(1), 139-146. https://doi.org/10.25134/erjee.v8i1.2011

Halcomb, E. J., \& Hickman, L. (2015). Mixed methods research. Research Online Faculty of Science, Medicine and Health University of Wollongong, 29(32), 41-47.

Hutchinson, T., \& Waters, A. (1987). English for specific purposes. Cambridge: Cambridge University Press.

Ibrahim, H., Ali, H., Rahman, A., \& Salih, A. (2013). Perceived Views of Language Teachers on the Use of Needs Analysis in ESP Materials Writing. English Language Teaching, 6(3), 11-19. https://doi.org/10.5539/elt.v6n3p11

Iselin, A. R., Decoster, J., \& Salekin, R. T. (2009). Maturity in Adolescent and Young Adult Offenders: The Role of Cognitive Control. Law Hum Behav, 33, 455-469. https://doi.org/10.1007/s10979-008-9160-x

Ker, A. J., Chan, R., Fields, H. W., Beck, M., \& Rosenstiel, S. (2008). Esthetics and smile characteristics from the layperson's perspective: a computer-based survey study. JADA, 139 (October), 1318-1327.

Lynne Flowerdew. (2013). Needs Analysis and Curriculum Development in ESP. In B. Paltridge \& S. Starfield (Eds.), The Handbook of English for Specific Purposes (pp. 325346). West Sussex: John Wiley \& Sons, Inc.

Paltridge, B., \& Starfield, S. (2013). The Handbook of English for Specific. West Sussex: John Wiley \& Sons, Inc.

Saragih, E. (2014). Designing ESP Materials for Nursing Students Based On Needs Analysis. International Journal of Linguistics, 6(4), 59-70. https://doi.org/10.5296/ijl.v6i4.5983

Sönmez, H. (2019). An Examination of Needs Analysis Research in the Language Education Process. International Journal of Education \& Literacy Studies, 7(1), 8-17.

Wahyuni, S. (2017). Journal on English as a Foreign Language Developing Writing Materials Based on CTL Approach for Indonesian EFL Learners. Journal on English as a Foreign Language, 7(1), 97-118. 